DOI: 10.33766/2524-0323.91.295-306

УДК 343.13:343.5/6

Ю. М. Слухаєнко,

аспірант Луганського державного університету внутрішніх справ

імені Е. О. Дідоренка

(м. Сєвєродонецьк, Україна)

e-mail:delfifry@gmail.com

iDhttps:/ / orcid.org/0000-0002-5335-7420

\title{
КРИМІНАЛІСТИЧНА ХАРАКТЕРИСТИКА ДОМАШНЬОГО НАСИЛЬСТВА
}

У статті надана криміналістична характеристика домашнього насильства. До основних елементів криміналістичної характеристики домашнього насильства віднесено: способи підготовки, учинення та приховування; засоби вчинення; обстановка, місце та час; мотиви та цілі; слідова картина кримінального правопорушення; особа злочинщя; особа потерпілого. Проаналізовано кожний структурний елемент такого кримінального правопорушення. Розкрито зміст та зв' язки елементів криміналістичної характеристики домашнього насиљства, важливе місце в якій посідають взаємозв' язки слідової картини та способу вчинення.

Запропоновано класифікацію способів вчинення кримінальних правопорушень, пов' язаних із домашнім насильством, із метою подалышого використання цих даних для побудови слідчих версій.

Установлено, що домашнє насиљство супроводжуються виникненням специфічних слідів, що свідчать як про насильницький характер кримінального правопорушення, що розслідується, так і про його окремі обставини

Ключові слова: домашне насильство, криміналістична характеристика, спосіб, обстановка, слідова картина, особа злочинця, жертва.

Постановка проблеми. Одним із актуальних питань, які стоять перед державою та суспільством, є подолання будь-яких проявів насильства в сім'ї. Як одна з найбілыш розповсюджених форм порушення прав і свобод особи та основний чинник, що зумовлює розлучення сімейної пари, такий вид насильства є серйозною і масштабною проблемою, яка породжує безліч інших соціальних негараздів.

За офіційними даними Міністерства внутрішніх справ України, станом на 1 січня 2020 року на обліку в органах Національної поліції України за домашнє насильство перебувало 86 тис. осіб (з них 85 \% - чоловіки, 15 \% - жінки), які вчинили домашнє насильство або спонукали до такого насильства інших членів сім'ї. Так нині майже 65 тис. осіб, схильних до вчинення насильства, узято на облік, зокрема: за фізичне насиљьтво - 29,8 тис. осіб; психологічне - 16,5 тис. осіб; економічне - 1,7 тис. осіб. Причому, працівниками поліщії винесено офіційних попереджень та захисних приписів - 4,8 тис [1; 2]. Такі статистичні дані свідчать про те, що після ухвалення Верховною Радою України Закону України «Про запобігання та протидію домашньому насильству» [3], кількість звернень громадян до поліції у зв' язку із вчиненням домашнього насильства зросла на $10 \%$.

(C) Слухаєнко Ю.М., 2020 
Нині проблема сімейного насилства тільки набуває усвідомлення і стає об'єктом громадської і державної політики. Виділення проблеми насильства в родині як глобальної соціальної проблеми - тільки перший крок, спрямований на їі розв'язання. На цьому шляху виникає чимало перешкод: недостатність вичерпної інформації про ступінь поширення і причини застосування сили в сім’ї, відсутність чітких визначень та теоретичної бази, недосконалість законодавства в частині відповідальності за протиправні діяння тощо. Водночас, через побоювання або небажання жертв привселюдно заявити про такі факти, прояви сімейного насильства мають латентний характер, що не може не позначитись негативно на стані подолання цього феномену. Насильство в родині руйнує фундамент безпеки як самої сім'ї, так і суспільства. Саме проблема насильства в сім'ї тісно пов' язана з такими явищами, як зростання кількості розлучень, бездоглядність та безпритульність дітей, формування насильницького менталітету нації, жебракування, втрати загальнолюдських цінностей любові та взаєморозуміння. Крім того, це явище є одним із чинників формування адиктивної поведінки в особи та передумовою вчинення нею кримінальних правопорушень.

Аналіз останніх досліджень і публікацій. Вагомий внесок у дослідження теоретичних питань, пов'язаних із методикою розслідування кримінальних правопорушень внесли вчені-криміналісти України: В. П. Бахін, В. Д. Берназ, В. К. Весельський, А. Ф. Волобуєв, В. І. Галаган, В. Г. Гончаренко, В. А. Журавель, Н. І. Клименко, І. І. Когутич, О. Н. Колесніченко, В. П. Колмаков, В. О. Коновалова, І. І. Котюк, С. Д. Лук'янчиков, В. Т. Маляренко, М. В. Салтевський, М. Я. Сегай, В. В. Тіщенко, Л. Д. Удалова, П. В. Цимбал, К. О. Чаплинський, С. С. Чернявський, В. Ю. Шепітько та інші. Актуальність теми домашнього насилства висвітлювалися в низці наукових праць, зокрема: Л. В. Крижної (2000 р.); Б. М. Головкіна (2002 р.); О. І. Белової (2006 р.); О. В. Ковальової (2008 р.); О. І. Зазимка (2010 р.); О. Д. Коломойщя (2010 р.); М. Ю. Самченко (2011 р.); А. Б. Благої (2015 р.); М. Г. Кузнєцова (2019 р.); Р. В. Кифлюка (2020 р.). Водночас, такі дослідження об' єктивно обмежувались попередніми періодами розвитку законодавства, а тому не повною мірою враховують та не завжди відповідають потребам правозастосовної практики. У значній кількості розроблень не враховано проблеми практики розслідування домашнього насильства, що виникли в умовах застосування нового кримінального процесуального законодавства та організаційно-структурних перетворень у системі правоохоронних органів України. Тому на сьогодні існує потреба у виокремленні та характеристищі структурних елементів криміналістичної характеристики домашнього насильста з метою ефективного досудового розслідування таких кримінальних правопорушень.

Формулювання цілей. Мета статті - розкрити значення криміналістичної характеристики, змісту та взаємозв'язків їі елементів у формуванні методики розслідування домашнього насильства; виокремитиструктурні елементи криміналістичної характеристики такого кримінального правопорушення та надати їх характеристику.

Виклад основного матеріалу. Уперше криміналістичну характеристику злочинів та їх елементи надав у своїх роботах А. М. Колесниченко [4, с. 18]. Його теоретичну ідею підтримало багато вчених, і тому вивчення цього питання одержало свій 
подалыший розвиток. Учені-криміналісти, що досліджують проблеми криміналістичної характеристики, не завжди однозначно підходять до визначення ії поняття й системи [5, с. 112].

Як зазначалося вище, науковці по-різному розглядають поняття криміналістичної характеристики злочину. Так Л. Я. Драпкін розглядає іï як «...наукову категорію, у якій з достатнім ступенем конкретності описані типові ознаки й властивості події, обстановки, способу та механізму вчинення суспільно-небезпечних діянь певної класифікаційної групи, процесу виникнення та локалізації доказів, типових ознак особистості та поведінки винних, потерпілих, а також стійкі особливості інших об'єктів посягань» [6, с. 17].

Р. С. Бєлкін зазначає, що криміналістична характеристика окремого виду злочину повинна містити в собі характеристику типової вихідної інформації, систему даних про способи вчинення і приховання цього виду злочинів і типових наслідків ix застосування, характеристику особистості типового злочинця, типових мотивів і цілей злочину, особистості потерпілих, деяких обставин вчинення злочину (часу, місця, обстановки) [7].

В. Г. Гончаренко розглядає зазначену категорію як ідеальну модель типових зв' язків і джерел доказової інформації, що закономірно формуються, і дозволяє прогнозувати оптимальний шлях та найбільш ефективні засоби розслідування окремих категорій злочинів [8, с. 12]. Він же пропонує розглядати ії на філософському рівні, інтерпретувавши як абстрактну інформаційну структуру розслідуваної події даного виду, закономірно й детерміновано відображеної в реальному світі. У якості складових елементів криміналістичної характеристики злочинів автори пропонують такі елементи: тип (вид, рід, категорія) події; засіб вчинення і приховання злочину; типові джерела матеріально-фіксованої інформації; типові джерела вербальної інформації; коло осіб, де може знаходитися особа, що вчинила злочин; типові мотиви і цілі вчинення такого роду злочинів [8, с. 15].

А. Ф. Волобуєв зі свого боку вважає, що криміналістична характеристика - це система відомостей (знань) про елементи механізму скоєння злочинів окремого виду або групи, у яких відображаються закономірні зв' язки між цими елементами і які використовуються для побудови і перевірки версій під час розслідування конкретних злочинів [9, с. 24].

Криміналістична характеристика кримінального правопорушення має надзвичайно важливе значення для розкриття і розслідування домашнього насильства. Перед слідчим постійно виникає необхідність звернення до того чи іншого ії елементу з метою уточнення своїх дій або ж прогнозування дій злочинця, для постановки правильних питань під час проведення експертизи або ж у процесі спілкування 3 фахівцем у певній галузі - у кожному випадку він неодноразово звертається до кількісних та якісних компонентів криміналістичної характеристики. При формуванні методики розслідування домашнього насильства, особливу увагу слід звертати на зв'язки елементів криміналістичної характеристики. До основних елементів криміналістичної характеристики домашнього насильства необхідно віднести: способи підготовки, учинення та приховування; засоби вчинення; обстановку, місце та час; мотиви та цілі; слідову картину кримінального правопорушення; особу злочинщя; особу потерпілого. 
Типові відомості про спосіб вчинення кримінального правопорушення визначаються більшістю вчених-криміналістів яК найважливіший (а іноді і як ключовий) елемент криміналістичної характеристики. Підстав для об’ єднання в групи способів вчинення кримінальних правопорушень, пов'язаних із домашнім насильством, може бути декілька, однак із урахуванням існуючих класифікацій [10, с. 128]. Із метою подалышого використання цих даних для побудови слідчих версій, варто запропонувати таку їх класифікацію:

За способом підготовки:

- з попереднъюю підготовкою - вчиняється досить не великий відсоток кримінальних правопорушень, пов'язаних із домашнім насильством (14 \%). Як правило, це вбивство або умисне спричинення тяжкої шкоди здоров'ю кривдника зі сторони потерпілого, який не бачить іншої можливості позбавитися кривдника. Це обумовлено тим фактором, що кривдник не погоджується на розлучення з потерпілим, оскільки це може тягнути за собою зміну матеріального стану (наприклад, розподіл квартири). У тому випадку, якщо в жінкиє можливість проживати окремо від кривдника (наприклад, переїзд до батьків), то кривдник продовжує їі переслідування.

- без попереднъої підготовки - основна кількість кримінальних правопорушень, пов' язаних із домашнім насильством, вчиняється спонтанно, без попереднього умислу (86 \%). Відсутність умислу спостерігається як у кривдника, так і в потерпілого у випадку вчинення ним злочинних дій у відповідь. Приводом для насильства з боку кривдника можуть бути будь-які обставини, що на його погляд свідчать про неповажне ставлення до нього з боку членів сім' ї, як-от: несмачна їжа, невипрасуваний одяг, небажання потерпілого виконувати свої «подружні обов' язки» тощо.

3 огляду на аналіз кримінальних правопорушень, пов'язаних із домашнім насильством, можна виділити наступні способи вчинення психологічного насильства: знущання, тобто зла насмішка, глузування, а також образливий вчинок по відношенню до члена сім'ї; тяжка образа; протиправні або аморальні дії (бездіяльність), що не є фізичним або сексуальним насильством; систематична протиправна або аморальна поведінка, що призвела до довготривалої психотравмуючої ситуації; жорстке поводження, тобто суворе, різке, немилосердне, люте, жорстоке; систематичне приниження людської гідності; психічні страждання; використання матеріальної або іншої залежності потерпілого (потерпілої) [11, с. 55].

Аналіз кримінальних правопорушень, пов'язаних із домашнім насильством показав, що, як правило, у ході вчинення таких протиправних дій злочинець не використовує ніяких прийомів для його приховування.

Найбільш часто дії по приховуванню факту домашнього насильства виконуються після вчинення кримінального правопорушення. Причому, необхідно зауважити, що дані дії можуть вчинятися як злочинщем, так і потерпілим. Так після вчинення кримінального правопорушення потерпіла особа приховує сам факт насильства, нікому не повідомляє про це. Це пояснюється соромом потерпілої сторони, небажанням «виносити сміття з дому», а також погрозами з боку кривдника щодо витоку інформації і, як наслідок, погіршення ситуащії (наприклад, маскує тілесні ушкодження; умовляє інших членів сім'ї, перш за все, дітей, нікому не розповідати про те, що сталося). Саме даною обставиною обумовлений високий рівень латентності щодо даої категорії проваджень. 
За способом приховування:

а) без приховування кримінального правопорушення.

Як правило, лише у випадках, коли потерпілому від домашнього насильства необхідна термінова медична допомога, насильник не застосовує на початковому етапі дій для приховування вчиненого кримінального правопорушення. Пов'язане це з тим, що психологічно кривдник не завжди готовий до настання таких тяжких наслідків, тому частіше за все він перебуває в стані розгубленості і сам подає заяву до правоохоронних органів про те, що відбулося;

б) з приховуванням кримінального правопорушення.

Білышість випадків домашнього насильства вчиняється 3 подальшим приховуванням обставин кримінального правопорушення. Усі прийоми приховування можна поділити на три групи: дії, що вчиняються до, під час та після вчинення кримінального правопорушення.

Після вчинення домашнього насильства злочинщі використовують наступні прийоми приховування: погрози на адресу членів сім'ї, ïx залякування із забороною звертатися до правоохоронних органів; переховування від органів досудового розслідування. Як правило, підозрюваний використовує цей час для переконання потерпілої відмовитися від показань, які були дані раніше; знищення трупа або його розчленування; одночасно з попереднім способом вживаються заходи щодо знищення слідів, які знаходяться на місці вбивства, а саме: робиться ремонт квартири, повна або часткова заміна шпалер, перефарбовується підлога, здійснюється чистка м'яких меблів, килимів, прасування одягу тощо; імітуються активні пошуки потерпілого, розповсюджуються чутки про його від'їзд у справах; робиться звернення із заявою до правоохоронних органів про зникнення члена сім'ї чи інсценування іншого кримінального правопорушення. За відсутності на трупі тілесних ушкоджень, як правило, має місце інсценування нещасного випадку або самогубства потерпілого. Якщо тілесні ушкодження явно свідчать про насильницьку смерть, інсценується розбійний напад або скоєння вбивства в стані сильного душевного хвилювання, необхідної оборони або вбивство $з$ необережності [12, с. 275].

Аналіз практики показує, що кримінальні правопорушення, пов'язані 3 домашнім насильством, найчастіше вчинялися із застосуванням різних знарядь. Інструментом вчинення кримінального правопорушення при насильстві зазвичай використовується зброя (вогнепальна, холодна), колючо-ріжучі побутові та інші предмети. Однак, вважається, що випадки використання зброї як знаряддя насильства в домашній обстановці все-таки є нетиповими. У будь якому випадку зброя використовується лише при наявності їі в сім’ї і спеціально не здобувається. Найбільш типовими при вчиненні даних кримінальних правопорушень є використання підручних засобів господарсько-побутового призначення. Так 43,7 \% фізичного домашнього насильства вчиняються за допомогою предметів, що випадково попали під руку, як-от: ножі, ножиці - 47 \%, побутові предмети - 13 \% [13, с. 56].

Також 40 \% кримінальних правопорушень вчинялися без застосування знарядь шляхом побиття руками та ногами. Можливі й інші способи насильницьких дій без застосування додаткових знарядь. Інші насильнищькі дії, що призводять до фізичного болю, полягають у щипанні, викручуванні рук, защемленні частини тіла 
потерпілого за допомогою будь-яких засобів (наприклад, дверей) або без них, впливом на особу вогнем або іншими природніми біологічними факторами (шляхом використання, наприклад, тварин або комах) тощо, тобто якщо все це супроводжується нанесенням фізичного болю.

Без застосування додаткових знарядь вчиняються також погрози та психологічне насильство (20 \%). Обов' язковою ознакою погрози є спосіб їі вчинення, а саме погроза застосуванням фізичного насильства по відношенню до потерпілого або до інших осіб (дітей). Причому, останніми погроза має сприйматися як реальність. Погроза може бути словесною, символічною або обумовленою обстановкою скоєння кримінального правопорушення [14, с. 173].

Домашнє насильство характеризується не нормальною обстановкою в сімї. Вона, як правило, включає цілий комплекс життєвих негараздів і труднощів, що тривалий час накопичуються в умовах взаємного спілкування людей в сім'ї або в спільній квартирі [15, с. 12]. Найбільша кількість кримінальних правопорушень, пов' язаних із домашнім насильством, вчиняється в містах. Дані кримінальні правопорушення вчиняються в основному в місцях реєстрації підозрюваного (13,3 \%) або жертви (17,7 \%), а також спільного їх помешкання (63,3 \%). Це різні приміщення (домоволодіння, квартири, дачі, гуртожитки тощо), де в 45 \% кримінальні правопорушення вчиняються на кухні, в коридорі, кімнаті [1; 11;16].

Час вчинення домашнього насильства не піддається чіткій регламентації, хоча можна виділити вечір, або, якщо бути більш точним, то темна пора доби (з 18.00 до 6.00 - 56,7 \%). Половина всіх кримінальних правопорушень, пов'язаних із домашнім насильством, вчиняється напередодні вихідних, у вихідні чи святкові дні.

Кримінальні правопорушення, пов'язані з домашнім насильством, супроводжуються виникненням специфічних слідів, які свідчать як про насильницький характер кримінального правопорушення, що розслідується, так і про його окремі обставини. До них відносяться: сліди боротьби на місці події (перевернуті, поламані меблі тощо); тілесні ушкодження на потерпілому - подряпини, крововиливи, синщі, рани (як невеликі, поверхневі, так і пронизуючі), розтяжки, вивихи тощо; пошкодження на одязі потерпілого; сліди біологічного походження (кров, частини мозкової рідини, волосся тощо); тілесні ушкодження на тілі підозрюваного (сліди укусів, подряпини), як сліди опору потерпілого.

Наступним елементом криміналістичної характеристики є дані про особу можливого підозрюваного. Статевий розподіл кількості осіб, які вчиняють насильство в сім'ї, свідчить про суттєве домінування дорослих осіб чоловічої статі. Пік кримінальної активності осіб, які вчинили злочини, пов' язані з насильством в сім'ї, припадає на дві вікові категорії: 21-29 років та 30-39 років. За освітнім рівнем серед сімейних кривдників переважають особи з середньою освітою. Переважна більшість злочинців досліджуваної категорії (37 \%) були мешканщями міст; на другому місці - мешканщі сіл чи присілків - 31,2 \%; на третьому - обласних центрів (20,5 \%); і на четвертому місці - селищ (11,3 \%) [13, с. 13-14]. Залежно від кримінально-правових ознак особи, які вчинили злочини, що пов'язані 3 домашнім насильством, діяли одноосібно (92,6 \%). Як правило, це випадки, коли застосування насильства не можна було приховати від сторонніх, - настання смерті потерпілого від домашнього насильства або від захисту потерпілого, а також випадки, коли необхідне втручання лікаря при 
отриманих тілесних ушкодженнях різного ступеня тяжкості. Серед осіб, які вчинили злочини в групі як виконавці, виступили 69,6 \% винних, як організатори 17,4 \% як пособники - 4,3 \%, як підбурювачі - 8,7 \%. Жінки в півтора раза частіше, аніж чоловіки, вчиняли злочини в групі; і якщо чоловіки, в основному, були виконавцями злочину (83,3 \%), а підбурювачів серед них взагалі не виявлено, то жінки як організатори злочинів, пов' язаних із насильством в сім'ї, виступили у 21,4 \%, як виконавці - у 61 \%, як пособники - у 3,6 \%, як підбурювачі - у 14 \%. Варто виокремити досить високий рівень інтенсивності сімейного насильства серед осіб, притягнутих до адміністративної відповідальності за ст. 173-2 КУпАП: щороку майже кожен п'ятий продовжує свою протиправну поведінку й повторно вчиняє такі дії. Попередній кримінальний досвід мала третина сімейних кривдників. Однією 3 причин цього є неефективна практика реагування з боку судових органів, оскільки домінуючим видом стягнення (93,8 \%) залишається накладання штрафу, який вдалося стягнути лише в половині випадків [16, с. 14].

Серед морально-психологічних особливостей сімейних кривдників встановлено знижені морально-етичні норми та наявність специфічних психологічних ознак. Зокрема, більше ніж 3/4 сімейних кривдників мають виражені риси інтроверсії з флегматичним і меланхолічним типами темпераменту, що відрізняє їх від категорії загальнокримінальних насильницьких злочинців та одночасно це супроводжується підвищеним рівнем дратівливості, запальності, грубості з проявами вербальної та деструктивно спрямованої агресивності, яка в чоловіків частіше поєднується з фізичною агресією.

Дослідження осіб, що вчинили домашнє насильство, дало змогу виділити за ступенем стійкості агресивно-насильнищького спрямування чотири їх основних типи:

- легковажний. До моменту вчинення протиправного діяння вони мали позитивну чи нейтральну характеристику, дотримувалися встановлених сімейних правил та установок. Якщо така особа й мала якісь негативні прояви поведінки або аморальні елементи свідомості, то вони були не помітні й проявлялися в мінімально;

- проміжний. Представники даного типу мають негативну характеристику, у минулому були випадки, коли допускалися порушення морально-етичних норм шляхом вчинення протиправних діянь, у тому числі насильницького характеру у родинних відносинах. Також спостерігалося неналежне виконання вимог, правил, встановлених суспільством, проте спрямованість яких на вчинення насильницьких посягань проти особи явно не виражена. Вчинення ними дій, які носять насильницький характер і належать до розряду кримінальних правопорушень нерідко стає для них способом досягнення мети, до якої вони йшли і вона має для них велике значення, способом заволодіння певним соціальним благом (наприклад, затвердження в ролі голови сімейства, самоствердження, підкорення своїй владі, заволодіння матеріальними благами тощо);

- агресивний. Основними характерними особливостями осіб даного типу є чітко та стійко виражена агресивно-насильницька спрямованість, сформованість стереотипу застосування грубої сили. Їх становлення відбувалося в обстановці, де норми правильної законної поведінки не мали абсолютно ніякої цінності. Домашнє насильство в їхній родині вважалося звичайним способом життя та було обгрунтоване 
стійкими поглядами антисуспільного спрямування, асоціальними установками та орієнтаціями. Вони вели аморальний, антисуспільний спосіб життя;

- зіснии. Характерною особливістю такого типу є агресивно-насильницька спрямованість, яка мала глибоко укорінений характер, домінуючий, злісний характер, у результаті чого їх злочинні дії в значній мірі втратили ситуащійний характер. У відносинах з представниками даного типу провокація з боку потерпілих не мала місця або не сумісна з тяжкістю наслідків, що наступила. Зазвичай вони самі створюють конфліктні ситуащії, провокують їх, щоб потім задовольнити своє бажання застосувати до потерпілого насильсто. Часто домашнє насильство вчинялось ними в умовах відсутності будь-яких міжособистісних протиріч. У них спостерігається максимально високий рівень агресивності, яка є для них домінуючим способом самоствердження, носила характер самоцінності. Тому домашнє насильство вони вчиняли не заради задоволення будь-яких раціональних цілей, а як самоціль.

У криміналістичній літературі зазначається, що глибоке дослідження особи потерпілого, його поведінки, взаємовідносин з оточуючими, характеру, схильностей та звичок є підставою для побудови основної версії про особу, що вчинила кримінальне правопорушення [17, с. 28].

Стосунки потерпілого і підозрюваного характеризуються близькими відношеннями, вони є членами однієї сім'ї. Так кримінальні правопорушення пов' язані 3 домашнім насильством, вчиняються відносно: одного $з$ подружжя (30 \%), співмешканщя (10 \%), батьків (23,3 \%), дітей (9\%); інших категорій родичів, що проживають ра$30 \mathrm{M}(27,7 \%)$.

Відповідно до соціального становища можна виділити наступні категорії: безробітні (47,7 \%), домогосподарки (13,3 \%), пращюючі (37,7 \%), пенсіонери (1,3 \%). За біофізичними характеристиками потерпілих можна класифікувати на жінок (43,3 \%) віком від 18 до 25 років - 13,3 \%, від 25 до 50 років - 86,7 \%; та чоловіків - від 10 до 18 років (7,7 \%), від 18 до 25 років - 17,4 \%, від 25 до 50 років - 61,9 \%; старші за 50 років - 13 \%.

Як правило, потерпілі від домашнього насильства є пасивними потерпілими, які дають повні та правдиві показання, що заслуговують довіри, але поводять вони себе під час слідства неактивно. Вирішення всіх питань, що виникають у процесі розслідування, а потім і на суді, залишають на розсуд слідчого і судді, клопотань на слідстві не заявляють, і зазвичай відмовляються знайомитися з матеріалами закінченого досудового розслідування. Нерідко доводиться переконувати таких потерпілих у необхідності їхньої участі в тій або іншій слідчій (розшуковій) дії.

Висновки. Підсумовуючи викладені в цій статті положення, слід зробити висновок, що теоретична значимість дослідження полягає в тому, що методика розслідування домашнього насильства становить нову галузь знань у криміналістищі, а саме домашнє насильство - криміналістично цілісним явищем із власними закономірностями функціонування й розвитку.

Варто наголосити, що домашнє насильство - це процес, що складається з протиправного, винного, систематичного фізичного або психічного впливу на членів сім'ї проти їх волі, з метою змусити їх вчинити небажані дії шляхом заподіяння їм болю, образи, фізичного знущання як погрози або покарання. Криміналістичну характеристику домашнього насильства необхідно розглядати як сукупність взаємозалеж- 
них, динамічних загальних та індивідуальних ознак вчиненого кримінального правопорушення, що відображають об'єктивну інформащію про спосіб, обстановку вчинення правопорушення, механізм утворення його слідів, особу потерпілого та особу злочинщя, на підставі якої визначаються напрямки розслідування кримінального правопорушення. Відомості про умови вчинення є системоутворюючим елементом, позаяк сфера вчинення таких кримінальних правопорушень обмежена поняттям «будинок», «Домашній». Домашнє насильство характеризується ненормальною обстановкою в сім'ї, яка, як правило, містить цілий комплекс життєвих негараздів і труднощів, образ, що тривалий час накопичуються в умовах спільного спілкування та проживання.

\section{Використані джерела:}

1. Довідка про злочини, учинені в Украӥні за 2015-2019 рр.: службовий документ / Департамент аналітичної роботи та організації управління МВС України. Київ, 2019. 124 с.

2. Кузнєцов М. Г. Домашне насильство: кримінологічна характеристика та запобігання: автореф. Дис. ...канд. юрид. наук: 12.00 .08 «Кримінальне право та кримінологія; кримінально-виконавче право». Київ, 2019. 20 с.

3. Про запобігання та протидію домашньому насильству: Закон від 07.12.2017 p. № 2229-VIII. Верховна Рада Украӥни. URL:https:/ /zakon.rada.gov.ua/laws/show/2229-19\#Tеxt.

4. Колесниченко А. Н., Коновалова В. Е. Криминалистическая характеристика преступлений: учеб. пособ. Харьков: Юрид. ин-т, 1985. 92 с.

5. Весельський В. К. Криміналістична характеристика злочинів. Право України. 2001. № 5. C.112-114.

6. Драпкин Л. Я. Предмет доказывания и криминалистические характеристики преступлений. Криминалистические характеристики в методике расследования преступлений: межвуз. сб. науч. тр. Свердловск, 1978. Вып. 69. С. 16-17.

7. Белкин Р. С. Курс криминалистики. В 3 т. Т. 1: Общая теория криминалистики. Москва: Юристь, 1997. 408 с.

8. Гончаренко В. И., Кушнир Г. А., Подпалый В. Л. Понятие криминалистической характеристики преступлений. Криминалистика и судебная экспертиза. 1986. Вып. 33. С. 12-16.

9. Волобуєв А. Ф. Загальні положення криміналістичної методики: лекція. Харків: Унт внутр. справ, 1996.36 с.

10. Салтевський М. В. Криміналістика (у сучасному викладі): підручник. Київ: Кондор, 2005. 588 c.

11. Кифлюк Р. В. Особливості розслідування та судового розгляду кримінальних проваджень, пов'язаних з насильством в сім'ї: дис. . .канд. юрид. наук: 12.00.09. Ірпінь, 2020. 233 с.

12. Бондаренко О. Г. Криміналістична характеристика заподіяння тяжких тілесних ушкоджень, що спричинити смерть потерпілого. Боротьба з організованою злочинністю $i$ корупцією (теорія і практика). 2015. № 2 (35). С. 273-278.

13. Ревин В. П. Насильственные преступления в сфере семейно-бытовых отношений и проблемы их профилактики: метод. реком. Москва, 1993.56 с.

14. Кримінальна відповідальність за згвалтування та насильницьке задоволення статевої пристрасті неприродним способом: монографія / А. В. Савченко, В. В. Кузнецов, Д. П. Москаль та ін. Ужтород, 2012. 272 с.

15. Пащенко А. С. Особенности расследования преступлений, связанньх с домашним насилием: автореф. дис. ..канд. юрид. наук: 12.00 .09 «Уголовный процесс; криминалистика и судебная экспертиза; оперативно-разыскная деятельность». Волгоград, 2005. 25 с. 
16. Блага А. Б. Насильство в сім'ї: кримінологічний вимір, детермінація, запобігання: автореф. дис. . .докт. юрид. наук: 12.00 .08 «Кримінальнеправо та кримінологія; кримінальновиконавче право». Харків, 2014. 39 с.

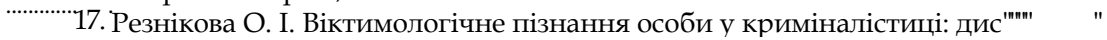

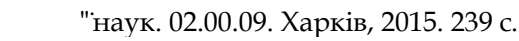

\section{References:}

1. Dovidka pro zlochyny, uchyneni v Ukraini za 2015-2019 rr.: sluzhbovyi dokument. (2019) Departament analitychnoi roboty ta orhanizatsii upravlinnia MVS Ukrainy. Kyiv. [in Ukrainian].

2. Kuznietsov, M. H. Domashnie nasylstvo: kryminolohichna kharakterystyka ta zapobihannia. Extended abstract of candidate's thesis. Kyiv. [in Ukrainian].

3. Pro zapobihannia ta protydiiu domashnomu nasylstvu: Zakon vid 07.12.2017 r. № 2229VIII. (2017) Verkhorna Rada Ukrainy - Verkhorna Rada of Ukraine. URL:https://zakon. rada.gov.ua/ laws/show/2229-19\#Text. [in Ukrainian].

4. Kolesnichenko, A. N., Konovalova, V. E. (1985) Kriminalisticheskaya harakteristika prestuplenij: ucheb. posob. Harkiv: Yurid. in-t. [in Russian].

5. Veselskyi, V. K. (2001) Kryminalistychna kharakterystyka zlochyniv. Pravo Ukrainy - Law of Ukraine,5, 112-114. [in Ukrainian].

6. Drapki,n L. Ya. (1978) Predmet dokazyvaniya i kriminalisticheskie harakteristiki prestuplenij. Kriminalisticheskie harakteristiki v metodike rassledovaniya prestuplenij: mezhouz. sb. nauch. tr.- Forensic characteristics in the methodology of crime investigation. Sverdlovsk, issue 69, 16-17. [in Russian].

7. Belkin, R. S. Kurs kriminalistiki. (1997) (Vol 1-3; Vol. 1): Obshaya teoriya kriminalistiki. Moskva: Yurist. [in Russian].

8. Goncharenko, V. I., Kushnir, G. A., Podpalyj, V. L. (1986) Ponyatie kriminalisticheskoj harakteristiki prestuplenij. Kriminalistika i sudebnaya ekspertiza- Forensics and forensics, issue 33, 12-16. [in Russian].

9. Volobuiev, A. F. (1996) Zahalni polozhennia kryminalistychnoi metodyky: lektsiia. Kharkiv: Un-t vnutr. sprav. [in Ukrainian].

10. Saltevskyi, M. V. (2005) Kryminalistyka (u suchasnomu vykladi): pidruchnyk. Kyiv: Kondor. [in Ukrainian].

11. Kyfliuk, R. V. (2020) Osoblyvosti rozsliduvannia ta sudovoho rozghliadu kryminalnykh provadzhen, pov'iazanykh z nasylstvom v sim'i. Candidate's thesis. Irpin. [in Ukrainian].

12. Bondarenko, O. H. (2015) Kryminalistychna kharakterystyka zapodiiannia tiazhkykh tilesnykh ushkodzhen, shcho sprychynyly smert poterpiloho. Borotba z orhanizovanoiu zlochynnistiu $i$ koruptsiieiu (teoriia i praktyka.- Fight against organized crime and corruption (theory and practice), 2(35), 273 278. [in Ukrainian].

13. Revin, V. P. (1993) Nasilstvennye prestupleniya v sfere semejno-bytovyh otnoshenij i problemy ih profilaktiki: metod. rekom. Moskva. [in Russian].

14. Kryminalna vidpovidalnist za zgvaltuvannia ta nasylnytske zadovolennia statevoi prystrasti nepryrodnym sposobom: monohrafiia. (2012) A. V. Savchenko, V. V. Kuznetsov, D. P. Moskal (Eds.) et al. Uzhhorod. [in Ukrainian].

15. Pashenko, A. S. (2005) Osobennosti rassledovaniya prestuplenij, svyazannyh s domashnim nasiliem. Extended abstract of candidate's thesis. Volgograd. [in Russian].

16. Blaha, A. B. (2014) Nasylstvo v sim'i: kryminolohichnyi vymir, determinatsiia, zapobihannia. Extended abstract of Doctor's thesis. Kharkiv. [in Ukrainian].

17. Reznikova O. I. Viktymolohichne piznannia osoby u kryminalistytsi: Candidate's thesis. Kharkiv. [in Ukrainian]. 


\section{Слухаенко Ю. Н.,} аспирант Луганского государственного университета внутренних дел имени Э. А. Дидоренко (г. Северодонецк, Украина)

\section{КРИМИНАЛИСТИЧЕСКАЯ ХАРАКТЕРИСТИКА ДОМАШНЕГО НАСИЛИЯ}

В статье предоставлена криминалистическая характеристика домашнего насилия. К основным элементам криминалистической характеристики домашнего насилия отнесены: способы подготовки, совершения и сокрытия; средства совершения; обстановка, место и время; мотивы и цели; следовая картина уголовного правонарушения; личность преступника; личность потерпевшего.

Проанализированы каждый структурный элемент такого уголовного преступления. Раскрыто содержание и связи элементов криминалистической характеристики домашнего насилия, важное место в которой занимают взаимосвязи следовой картины и способа совершения.

Предложена классификация способов совершения уголовных преступлений, связанных с домашним насилием, с целью дальнейшего использования этих данных для построения следственных версий.

Установлено, что домашнее насилие сопровождаются возникновением специфических следов, свидетельствующих как о насильственном характере уголовного правонарушения, расследуется, так и о его отдельные обстоятельства.

Ключевые слова: домашнее насилие, криминалистическая характеристика, способ, обстановка, следовая картина, личность преступника, жертва.

\section{Slukhaenko Yu., Graduate Student of Luhansk State University University of Internal Affairs named after E. Didorenko (Sievierodonetsk, Ukraine)}

\section{CRIMINAL CHARACTERISTICS OF DOMESTIC VIOLENCE}

The article provides a forensic description of domestic violence. The main elements of the forensic characteristics of domestic violence include: methods of preparation, commission and concealment; means of commission; situation, place and time; motives and goals; trace picture of a criminal offense; the identity of the offender; the person of the victim. Each structural element of such a criminal offense is analyzed and the author's classification of ways of its commission is offered. The content and connections of elements of criminological characteristics of domestic violence (method of preparation, commission and concealment of criminal offenses; circumstances of commission; information about the person who committed domestic violence; trace picture) are revealed. , because the nature and location of traces are directly determined by the actions of the perpetrators, who in a certain situation choose the victim of criminal encroachment, leaving forensically significant reflections on it and the study of which is most important to establish signs of a criminal offense. 
The classification of ways of committing criminal offenses related to domestic violence is proposed, in order to further use this data to build investigative versions: by method of preparation: with prior training; without prior training; by way of concealment: without concealment of a criminal offense; with concealment of a criminal offense.

It was established that domestic violence is accompanied by the appearance of specific traces that indicate both the violent nature of the criminal offense under investigation and its individual circumstances (traces of fighting at the scene; injuries to the victim, stretch marks, dislocations, etc.; damage to the victim's clothing; traces of biological origin). The most common cases of domestic violence are criminal acts of physical violence, which are characterized by the predominance of young criminals of a fairly young age, who at the time of its commission did not work or study, abused alcohol, had mental or behavioral disorders. Classification is provided.

Female and male victims of physical violence in the family are equally common. The situation of committing such criminal offenses shows that they are the result of a long conflict; more than half of the cases occurred in urban areas and were recorded in all types of families, regardless of their level of wealth. The mechanism of committing crimes that belong to the category of physical violence in the family is largely determined by the willful rational purposeful type of motivation for criminal activity. Among the motives for committing crimes play a significant role revenge, irritation of the victim's behavior, jealousy, selfish motive.

Keywords: domestic violence, forensic characteristics, method, situation, trace picture, identity of the offender, victim. 